\title{
Preliminary Investigation of Bioactive Compounds and Bioautographic Studies of Whole Plant Extract of Euphorbia pulcherrima on Escherichia coli, Staphylococcus aureus, Salmonella typhi, and Pseudomonas aeruginosa
}

\author{
H. B. Sharif, ${ }^{1}$ M. D. Mukhtar, ${ }^{2}$ Y. Mustapha, ${ }^{2}$ and A. O. Lawal ${ }^{1}$ \\ ${ }^{1}$ Department of Applied Science, College of Science and Technology, Kaduna Polytechnic, PMB 2021, Kaduna, Nigeria \\ ${ }^{2}$ Department of Microbiology, Bayero University, Kano, Nigeria
}

Correspondence should be addressed to H. B. Sharif; sharifgoshi@yahoo.com

Received 14 August 2014; Revised 9 December 2014; Accepted 14 December 2014

Academic Editor: Barbara R. Conway

Copyright (C) 2015 H. B. Sharif et al. This is an open access article distributed under the Creative Commons Attribution License, which permits unrestricted use, distribution, and reproduction in any medium, provided the original work is properly cited.

\begin{abstract}
The aim of this study is to carry out preliminary investigation of bioactive compounds and bioautographic studies of whole plant extract of Euphorbia pulcherrima on Escherichia coli, Staphylococcus aureus, Salmonella typhi, and Pseudomonas aeruginosa. Tukey HSD test of hierarchy for the effect of different solvents crude extract on bacterial isolates indicates the methanol extract as the most bioactive. The Tukey HSD analysis also showed that the bioactivities of the crude extracts of the various parts of Euphorbia pulcherrima were part dependent and the whole plant was the most bioactive. The ethyl acetate fraction of the methanol extract of the whole plant of Euphorbia pulcherrima has been shown in this work to contain phytochemicals which have shown remarkable activities against Escherichia coli, Staphylococcus aureus, Salmonella typhi, and Pseudomonas aeruginosa. The bioactivities against the test organisms were due to the combined effects of the compounds separated on TLC plates. Families of terpenoids, flavonoids, alkaloids, saponin, and steroids that were detected in the extracts were identified by GC-MS. The various classes of phytochemicals in the E. pulcherrima plant provided the antimicrobial potency of the plant.
\end{abstract}

\section{Introduction}

The search for solutions to the global problems of antibiotic resistance in pathogenic microorganisms has often been driven on the isolation and characterization of new antimicrobial compounds from a variety of sources including medicinal plants [1]. Investigations into toxicity of medicinal plants have been reported by [2-4]. However, there is still an increasing interest in the use of medicinal herbs for meeting the goal of primary health care delivery worldwide $[5,6]$.

The plant family Euphorbiaceae contains skin irritating and tumor promoting diterpenoids [7].

However, some species are used in folk medicine to treat skin diseases, gonorrhea, migraine, intestinal parasites, and warts [8]. The broad range and diversity of biological activities in the Euphorbia genus may be due to the presence of various components in the plants with different modes of action $[9,10]$.

The active principles of many drugs found in plants are secondary metabolites [11, 12]. However, there is scanty literature on the bioactive secondary metabolites possessed by Euphorbia pulcherrima that may be responsible for its curative effect.

This present study focused on identification of bioactive compounds in whole plant extract of Euphorbia pulcherrima and bioautographic studies of the whole plant extract with Escherichia coli, Staphylococcus aureus, S. typhi, and Ps. aeruginosa as test organisms. Bioautography is a microbial 
detection method hyphenated with planar chromatography techniques. It is based mainly on antimicrobial or antifungal properties of analyzed substances. The selection of E. pulcherrima for investigation premised on its use and efficacy in the African ethnopharmacopoeia to treat gastroenteritis related ailments [13], despite its acclaimed toxicity. The medicinal properties of the plant are also contraindicated in the local treatment of respiratory tract infection, malaria, eczema, asthma, and wound healing properties.

\section{Materials and Method}

2.1. Collection and Authentication of Samples of Euphorbia pulcherrima Plant. The samples of E. pulcherrima were collected from the bushes along Gwarzo road, Kano State, Nigeria, at different sites between November and December 2013. The plants were authenticated at the Herbarium of the Department of Biological Sciences, Bayero University, Kano.

2.2. Preparation of Plant Samples. The E. pulcherrima whole plant samples were washed with distilled water and dried at room temperature in the biological garden at the Department of Applied Science, Kaduna Polytechnic. Dried E. pulcherrima samples were crushed and pulverized using sterilized mortar and pestle. The plant powder was exhaustively and successively extracted with methanol, ethanol, and water in Soxhlet extractor. $500 \mathrm{~g}$ of plant was used for the extraction from which the crude extract was obtained. $100 \mathrm{mg} / \mathrm{mL}$, $50 \mathrm{mg} / \mathrm{mL}$, and $25 \mathrm{mg} / \mathrm{mL}$ of the crude extract were used to carry out the antimicrobial activity evaluation against the test organisms. The methanol extract was used to carry out further analyses as it indicated the highest activity against the test organisms. Preliminary antimicrobial activity studies confirmed the methanol extract as the most bioactive against Escherichia coli, Staphylococcus aureus, S. typhi, and Ps. aeruginosa as test organisms.

2.3. Chromatographic Studies. The crude methanol extract of whole plant of E. pulcherrima (L) was fractionated using ethyl acetate. The whole plant ethyl acetate fraction was subjected to thin layer chromatography (TLC) using normal TLC precoated silica gel G micro slides. Various solvent systems consisting of hexane and ethyl acetate in the ratios $9: 1$, $4: 1,7: 3,3: 2$, and $1: 1$ were used at different concentrations to determine the solvent system that provided maximum separation of compounds when the slides were sprayed with p-anisaldehyde and visualized under UV light. Hexane : ethyl acetate in ratio $7: 3$ was used to separate the components of the extract and the Rf values were thus calculated. The developed chromatograms were subjected to antimicrobial activity test by the Agar overlay bioautography method (Onawumi, 2000) and observed the zones of inhibition on the TLC plates. The ethyl acetate fraction was used in its crude form.

2.3.1. Column Chromatography. The ethyl acetate extract used for the column chromatography was in crude form. The weight of the extract used was $4 \mathrm{~g}$. This was eluted with
$200 \mathrm{~mL}$ of $100 \% \mathrm{n}$-hexane first and then with varying ratios of hexane : ethyl acetate used. $20 \mathrm{~mL}$ of eluents was collected at intervals and similar compounds were pooled together after TLC.

A glass column of length $30 \mathrm{~cm}$ and width $3 \mathrm{~cm}$ parked with silica gel was used for the partitioning of the ethyl acetate fraction. The ethyl acetate fraction was first eluted with $200 \mathrm{~mL}$ of $100 \% \mathrm{n}$-hexane and two different sets of fractions were collected and labeled as A and B. The fraction obtained by eluting the column with $9: 1 \mathrm{n}$-hexane : ethyl acetate was labeled as C. n-Hexane : ethyl acetate in the ratio $4: 1$ eluted fractions D, E, F, and G. 7:3 n-hexane: ethyl acetate mixture eluted the fraction labeled $\mathrm{H}$. The fractions were further used to confirm the bioactivity of the ethyl acetate fraction.

2.4. FT-IR and GC-MS Analysis. The A, B, C, D, E, F, G, and $\mathrm{H}$ fractions obtained from the column chromatography were concentrated on rotary evaporator and analysed using GCMS-QP2010 Plus Shimadzu and FT-IR model 8400S scanned in accordance with ATSM1252-98 to determine the probable compounds responsible for the bioactivity of the fractions.

2.5. Characterization and Authentication of Test Organisms. The test organisms were typed cultures of E. coli ATCC 25922, Ps. aeruginosa ATCC 27853, S. aureus ATCC 25923, and the clinical isolates of $S$. typhi obtained from the Pharmaceutical Microbiology Laboratory, Department of Pharmaceutical Sciences, Ahmadu Bello University, Zaria. The standard strains of bacteria were grown on nutrient agar and tested for purity while the clinical isolates of $S$. typhi were characterized as described by Cheesebrough [14] by observing their cultural characteristics when subcultured on SS agar, MacConkey agar, and nutrient agar and the Gram staining reaction for bacteria. Biochemical tests for motility, citrate, and methyl red as positive confirmatory tests were performed for $S$. typhi.

2.6. Preparation and Standardization of Inocula. McFarland's standard method was adopted from Cheesebrough [14] to standardize the organisms to $1.0 \times 10^{8} \mathrm{cfu} / \mathrm{mL}$ using Genesys 20 spectrophotometer for the bacterial test organisms at $625 \mathrm{~nm}$ optical density.

2.7. Antimicrobial Susceptibility Test. The agar well diffusion method of the National Committee on Clinical Laboratory Standard [16] was adopted to test for the antimicrobial activity of the extracts on the test organisms. Sterile media plates of nutrient agar were prepared for the bacteria. These plates were then separately flooded with diluted standardized overnight cultures and then drained off to remove excess. Wells of $6 \mathrm{~mm}$ diameter were made in triplicate in each plate with a central well for the control using $6 \mathrm{~mm}$ sterile cork borer. The wells were filled with $0.1 \mathrm{~mL}$ of diluted concentrations of extracts with the aid of sterile pipettes per well. 100, 50, and $25 \mathrm{mg} / \mathrm{mL}$ of extract were used and $1 \mathrm{mg} / \mathrm{mL}$ of the standard antibiotics (ciprofloxacin $500 \mathrm{mg}$ and flucamed $50 \mathrm{mg}$ ) was used as positive controls. Sterile distilled water was used as negative control on a separate 
TABLE 1: Rf values for different compounds present in the ethyl acetate fraction.

\begin{tabular}{lcccccccc}
\hline Spots & 1 & 2 & 3 & 4 & 5 & 6 & 7 & 8 \\
\hline Rf values & 0.16 & 0.42 & 0.54 & 0.65 & 0.71 & 0.78 & 0.83 & 0.89 \\
\hline
\end{tabular}

TABLE 2: Different fractions of the ethyl acetate fraction partitioned on silica gel column.

\begin{tabular}{|c|c|c|c|c|}
\hline Serial number & Solvent system & Fractions eluted & Colour & Group \\
\hline 1 & n-Hexane & $1,2,3$ & Black & A \\
\hline 2 & n-Hexane & $4,5,6,7,8,9,10$ & Light green & B \\
\hline 3 & Hexane : ethyl acetate $(9: 1)$ & $11,12,13,14,15,16,17,18,19,20$ & White & $\mathrm{C}$ \\
\hline 4 & Hexane : ethyl acetate $(4: 1)$ & $21,22,23,24$ & Yellow & $\mathrm{D}$ \\
\hline 5 & Hexane : ethyl acetate $(4: 1)$ & $25,26,27,28,29,30,31,32,33$ & Dark brown & $\mathrm{E}$ \\
\hline 6 & Hexane : ethyl acetate $(4: 1)$ & $\begin{array}{c}34,35,36,37,38,39,40,41,42,43,44,45,46 \\
47,48\end{array}$ & Dark green & $\mathrm{F}$ \\
\hline 7 & Hexane : ethyl acetate $(4: 1)$ & $\begin{array}{c}49,50,51,52,53,54,55,56,57,58,59,60,61 \\
62\end{array}$ & Green & G \\
\hline 8 & Hexane : ethyl acetate $(7: 3)$ & $63,64,65,66,67,68$ & Brown & $\mathrm{H}$ \\
\hline
\end{tabular}

TABLE 3: FT-IR spectra of the ethyl acetate extract.

\begin{tabular}{lccc}
\hline Serial number & Peaks in ethyl acetate extract & Motion & Functional group \\
\hline 1 & 725.26 & & Aromatics \\
& 825.56 & C-H bending out of plane & Amines \\
esters & C-N stretching & C-O-C stretch & Esters \\
\hline 3 & 1041.6 & C-C $(\mathrm{O})-\mathrm{C}$ & Alkanes \\
\hline 4 & 1180.47 & $\mathrm{CH}_{3}$ bend & Alkanes \\
\hline 5 & 1249.91 & $\mathrm{CH}_{3}$ bend & Nitrogenous compounds \\
\hline 6 & 1373.36 & $\mathrm{~N}-\mathrm{H}$ stretching & Alcohol/phenol \\
\hline 7 & 1456 & O-H stretch & Phenol \\
\hline 9 & 1612.54 & C-O stretch & Aliphatic aldehydes \\
\hline 10 & 1651.12 & C=O stretching & Acid \\
\hline 11 & 3379.4 & Carboxylic acid O-H & stretch \\
\hline
\end{tabular}

plate. Diameters of zones inhibition were measured after incubating the plates at $37^{\circ} \mathrm{C}$ for $24 \mathrm{hrs}$ (bacteria). The plates were replicated in triplicate and the diameter of zones of inhibition was recorded.

2.8. Bioautographic Studies. The agar overlay method was adopted for the bioautographic studies. The agar media were applied directly onto the developed TLC plate of the whole plant ethyl acetate fraction, TLC chromatogram. $19 \mathrm{~mL}$ of molten nutrient agar was seeded with $1 \mathrm{~mL}$ of standardized overnight culture of the susceptible organism. This was poured over the developed chromatogram TLC plate kept in a Petri dish. This was allowed to solidify and prediffuse for $2 \mathrm{hrs}$ before incubation at $37^{\circ} \mathrm{C}$ for $24 \mathrm{hrs}$ for the bacterial isolates.
The plates were sprayed with aqueous solution of methyl thiazolyl tetrazolium (MTT) chloride for the detection of dehydrogenase activity. Zones of inhibition were observed as clear spots against purple background.

\section{Results}

The percentage yield for the E. pulcherrima methanol extract was $5.14 \%$ with dark green appearance and gummy texture. Ethanol extract was $4.55 \%$ with dark green appearance and gummy texture. The aqueous extract was $4.16 \%$ and appeared as a dark solid extract. The ethyl acetate fraction of the methanol extract was consistently giving higher 
TABLE 4: Phytochemicals in E. pulcherrima n-hexane fraction of ethyl acetate extract (A).

\begin{tabular}{|c|c|c|}
\hline $\begin{array}{l}\text { Peak } \\
\text { number }\end{array}$ & Name & Structure \\
\hline 4 & $\begin{array}{l}\text { 3-Fluorophenyl 2-fluoro-6- } \\
\text { (trifluoromethyl)benzoate }\end{array}$ & \\
\hline 14 & $\begin{array}{l}\text { 4-Bromophenyl heptyl phthalate } \\
\text { (wax) }\end{array}$ & \\
\hline 19 & $\begin{array}{c}\text { O-(3-(tert-Butyl)cyclohexa-2,4- } \\
\text { dien-1-yl) } \\
\text { (6-methoxypyridin-2- } \\
\text { yl)(methyl)carbamothioate } \\
\text { (alkaloid) }\end{array}$ & \\
\hline 34 & $\begin{array}{c}\text { Bis(4-methylheptan-3-yl) } \\
\text { phthalate } \\
\text { (wax) }\end{array}$ & \\
\hline
\end{tabular}

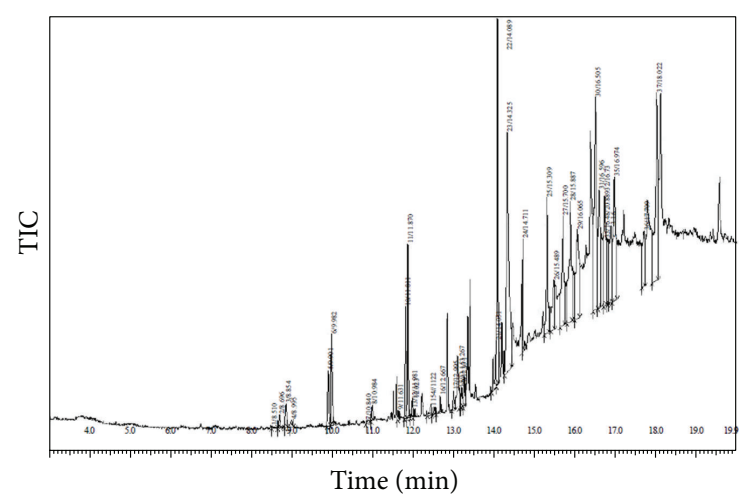

FIGURE 1: GC-MS chromatogram for Euphorbia pulcherrima nhexane fraction of ethyl acetate extract (A).

antimicrobial activity against the test organisms in comparison to other fractions and so it was used for the study.

3.1. Chromatography Studies. The thin layer chromatograms of the ethyl acetate fraction revealed the presence of eight compounds with different $\mathrm{Rf}$ values as shown in Table 1.

The partitioning of the ethyl acetate fraction on silica gel column using 100\% n-hexane, 9:1 hexane : ethyl acetate, $4: 1$ hexane : ethyl acetate, and 7:3 hexane : ethyl acetate also revealed sixty-eight fractions of different colours that were grouped into eight using the similarity in their Rf values (Table 2).

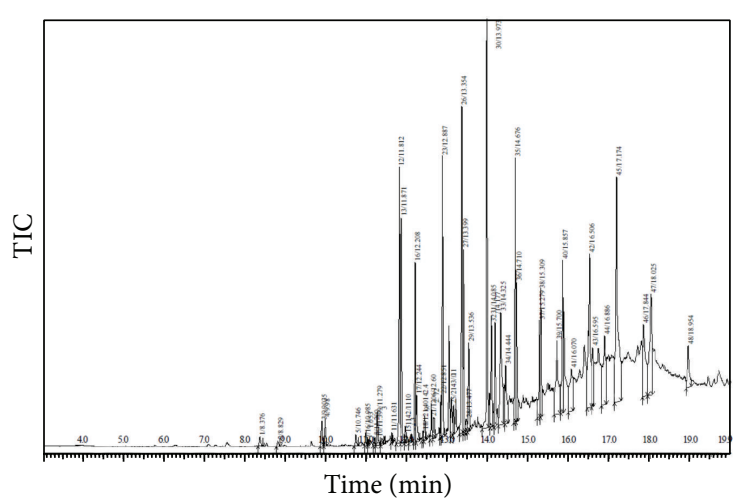

FIGURE 2: GC-MS chromatogram for Euphorbia pulcherrima nhexane fraction of ethyl acetate extract (B).

The results of the GC-MS analysis of fractions A, B, C, D, E, F, G, and $\mathrm{H}$ revealed different phytochemicals (terpenoids, flavonoids, alkaloids, saponin, and steroids) as shown in Tables 4-11. The chromatograms of the extracts are in Figures $1-8$. The presence of the compounds was further confirmed by functional groups such as<smiles>NC=O</smiles><smiles>COC(N)=O</smiles><smiles>CCO</smiles> 
TABLE 5: Phytochemicals in Euphorbia pulcherrima n-hexane fraction of ethyl acetate extract (B).

\begin{tabular}{llc}
\hline $\begin{array}{l}\text { Peak } \\
\text { number }\end{array}$ & Name & Structure \\
\hline
\end{tabular}

8

Menthyl acetate<smiles>CC(=O)OC1CC(C)CCC1C(C)C</smiles>

10

2,4,4-Trimethylpentyl 2-ethylbutanoate

(wax)

18

2,2,6-Trimethyl-7-(prop-1-en-2-yl)cyclooctane-1,5dione

19

Heptan-3-yl isobutyl phthalate

(wax)

4-(((Tetrahydrofuran-2-yl)methyl)amino)-1-

20 oxaspiro[4.5] dec-3-en-2-one

(alkaloid)
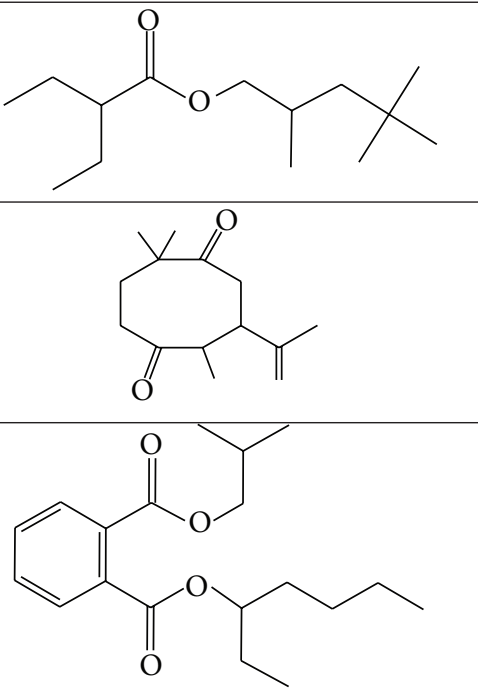

7,9-Di-tert-butyl-1-oxaspiro[4.5]deca-6,9-diene-2,8-

dione

(flavonoid)

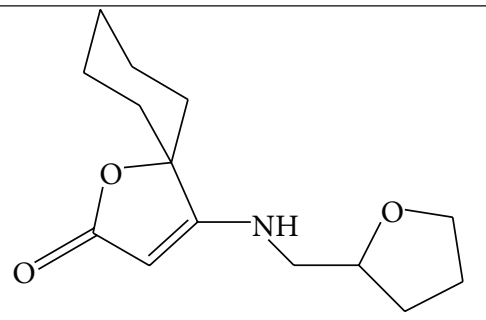

25

Butyl heptan-3-yl phthalate

(wax)
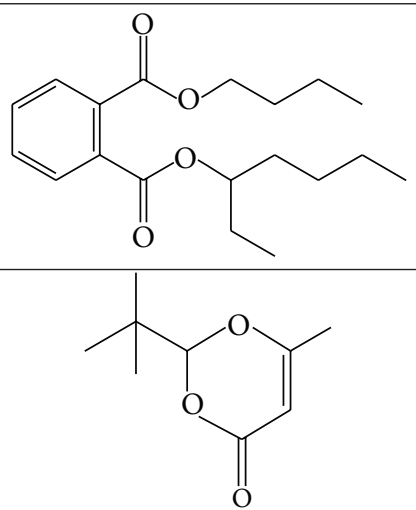
TABle 5: Continued.

Peak
number

39

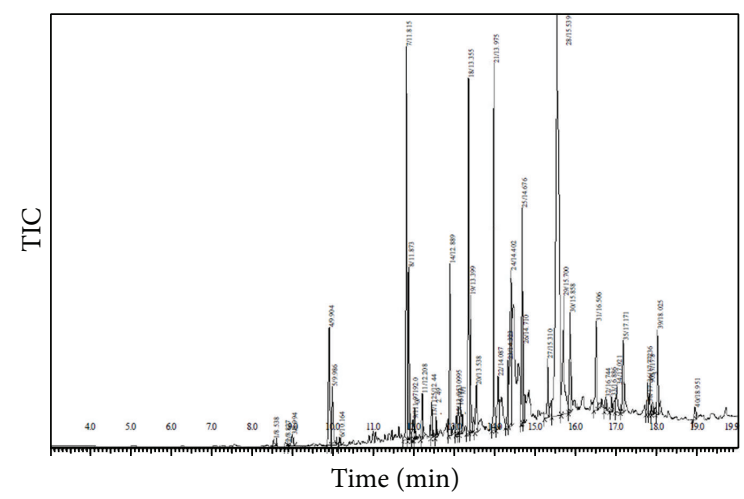

FIGURE 3: GC-MS chromatogram for Euphorbia pulcherrima hexane : ethyl acetate $(9: 1)$ fraction of ethyl acetate extract (C).

These functional groups were revealed by the FT-IR analysis of the ethyl acetate fraction (see Table 3).

3.2. Bioautography Studies. The results of the bioautography tests of ethyl acetate extract against E. coli (EC), Ps. aeruginosa (Ps), S. typhi (ST), and S. aureus (SA) are shown in Figure 9. It revealed that all the eight compounds separated by TLC had good activities against all the test organisms. Figure 9 compares the original TLC plates displaying the separated components with the developed TLC plate of the

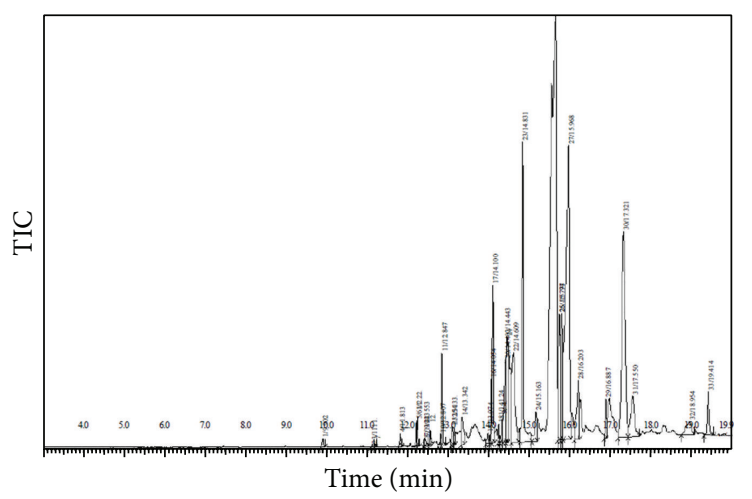

FIgURE 4: GC-MS chromatogram for Euphorbia pulcherrima hexane : ethyl acetate $(4: 1)$ fraction of ethyl acetate extract (D).

whole plant ethyl acetate fraction carrying $19 \mathrm{~mL}$ of molten nutrient agar which was seeded with $1 \mathrm{~mL}$ of standardized overnight culture of the susceptible organism in Petri dishes.

\section{Discussion}

The chromatogram of the Euphorbia pulcherrima extracts A, B, C, D, E, F, G, and H obtained from the GC-MS confirmed the numerous compounds extracted by the ethyl acetate 
TABLE 6: Phytochemicals in Euphorbia pulcherrima hexane : ethyl acetate $(9: 1)$ fraction of ethyl acetate extract (C).

\begin{tabular}{|c|c|c|}
\hline Peak & Name & Structure \\
\hline 1 & $\begin{array}{l}\text { 2,6-Di-tert-butylcyclohexa-2,5-diene-1,4-dione } \\
\text { (quinone) }\end{array}$ & \\
\hline 3 & $\begin{array}{l}\text { 2,4-Di-tert-butylphenol } \\
\text { (phenolic) }\end{array}$ & \\
\hline 12 & $\begin{array}{l}\text { Diisobutyl phthalate } \\
\text { (wax) }\end{array}$ & \\
\hline 14 & $\begin{array}{c}\text { 7,9-Di-tert-butyl-1-oxaspiro[4.5] deca-6,9-diene-2,8- } \\
\text { dione } \\
\text { (flavonoid) }\end{array}$ & \\
\hline 17 & $\begin{array}{l}\text { Dibutyl phthalate } \\
\text { (wax) }\end{array}$ & \\
\hline
\end{tabular}

4,4,6a,6b,8a,11,11,14b-Octamethyl-

24 $1,2,3,4,4 a, 5,6,6 a, 6 b, 7,8,8 a, 9,10,11,12,12 a, 14,14 a, 14 b-$ icosahydropicen-3-ol (steroid)
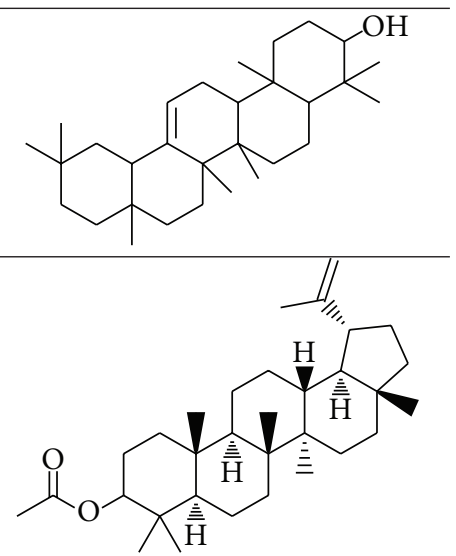

4-(3-Hydroxy-3-methylpentyl)-3,4a,8,8-

(saponin)<smiles>CCC(C)(O)CCC1C(C)CC(O)C2C(C)(C)CCCC12C</smiles> 
TABLE 7: Phytochemicals in Euphorbia pulcherrima hexane : ethyl acetate (4:1) fraction of ethyl acetate extract (D).

5 Peak

$4,4,6 \mathrm{a}, 6 \mathrm{~b}, 8 \mathrm{a}, 11,11,14 \mathrm{~b}-$ Octamethyl-

20

$1,2,3,4,4 a, 5,6,6 a, 6 b, 7,8,8 a, 9,10,11,12,12 a, 14,14 a, 14 b-$

icosahydropicen-3-ol

(steroid)

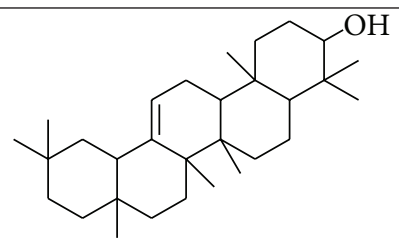

4,4,6a,6b,8a,11,11,14b-Octamethyl-

22 $1,2,3,4,4 a, 5,6,6 a, 6 b, 7,8,8 a, 9,10,11,12 b, 13,14,14 a, 14 b-$ icosahydropicen-3-ol (steroid)

$(8 S, 9 S, 10 R, 13 R, 14 S, 17 R)-17-((2 R, 5 R)-5$-Ethyl-6-methylheptan2-yl)-10,13-dimethyl-2,3,4,7,8,9,10,11,12,13,14,15,16,17tetradecahydro- $1 H$-cyclopenta $[a]$ phenanthren-3-yl nonadecanoate (steroid)

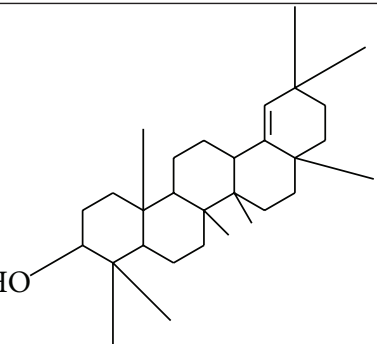

$\begin{gathered}\text { nonadecanoate } \\ \text { (steroid) }\end{gathered}$
25 4a,8,8a-Trimethyl-2-(prop-1-en-2-yl)-1,2,3,4,4a,5,6,8a-
octahydronaphthalene

3a-(Hydroxymethyl)-5a,5b,8,8,11a-pentamethyl-1-(prop-1-en-
2-yl)icosahydro-1H-cyclopenta[a]chrysen-9-ol
(saponin)


TABLE 7: Continued.

Peak
$\begin{aligned} & \text { 2a,5a,8,8-Tetramethyl-3-(6-methylheptan-2- } \\ & \text { yl)hexadecahydrocyclopenta[a]cyclopropa[e]phenanthrene } \\ & \text { (steroid) }\end{aligned}$

TABLE 8: Phytochemicals in Euphorbia pulcherrima hexane : ethyl acetate (4:1) fraction of ethyl acetate extract (E).

\begin{tabular}{|c|c|c|}
\hline Peak & Name & Structure \\
\hline 7 & $\begin{array}{l}\text { Diisobutyl phthalate } \\
\text { (wax) }\end{array}$ & \\
\hline 26 & $\begin{array}{c}\text { 5-Methyl-5-(4,8,12- } \\
\text { trimethyltridecyl)dihydrofuran-2(3H)- } \\
\text { one } \\
(\operatorname{wax})\end{array}$ & \\
\hline 29 & $\begin{array}{c}\text { Bis(2-ethylhexyl) phthalate } \\
\text { (wax) }\end{array}$ & \\
\hline 34 & $\begin{array}{c}\text { (E)-1,2-Bis(5-methylbenzo }[d] \text { oxazol-2- } \\
\text { yl)ethene } \\
\text { (alkaloid) }\end{array}$ & \\
\hline
\end{tabular}

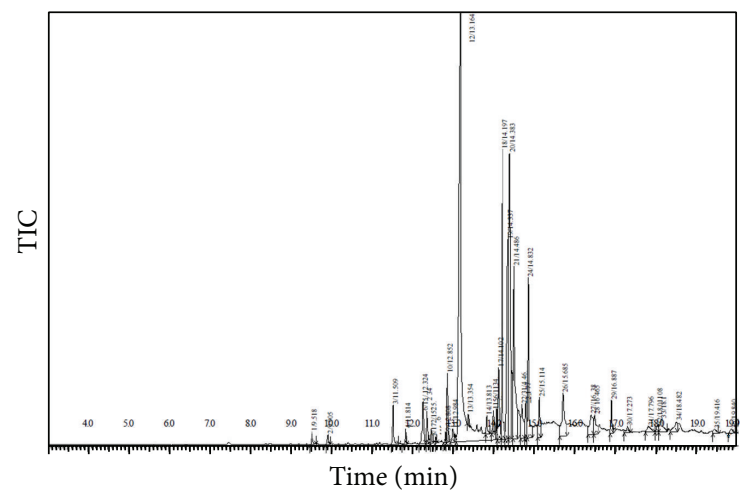

FIGURE 5: GC-MS chromatogram for Euphorbia pulcherrima hexane : ethyl acetate $(4: 1)$ fraction of ethyl acetate extract (E).

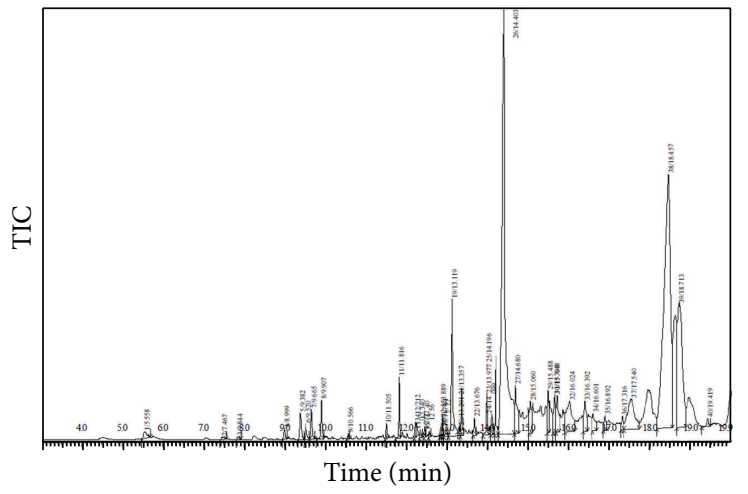

FIGURE 6: GC-MS chromatogram for Euphorbia pulcherrima hexane : ethyl acetate $(4: 1)$ fraction of ethyl acetate extract (F). 
TABLE 9: Phytochemicals in Euphorbia pulcherrima hexane : ethyl acetate $(4: 1)$ fraction of ethyl acetate extract (F).

\begin{tabular}{|c|c|c|}
\hline Peak & Name & Structure \\
\hline 1 & $\begin{array}{l}\text { 2-Phenylacetic acid } \\
\text { (wax) }\end{array}$ & \\
\hline 3 & $\begin{array}{l}\text { 4-(2-Hydroxyethyl)-2-methoxyphenol } \\
\text { (phenolic) }\end{array}$ & \\
\hline 4 & $\begin{array}{l}\text { 2,4-Di-tert-butylphenol } \\
\quad \text { (terpenoid) }\end{array}$ & \\
\hline 5 & $\begin{array}{c}\text { 4,4,7a-Trimethyl-5,6,7,7a-tetrahydrobenzofuran- } \\
\text { 2(4H)-one } \\
\text { (steroid) }\end{array}$ & \\
\hline 9 & $\begin{array}{l}\text { Triethyl 2-hydroxypropane-1,2,3-tricarboxylate } \\
\text { (wax) }\end{array}$ & \\
\hline 32 & $\begin{array}{c}\text { (E)-17-(5-Ethyl-6-methylhept-3-en-2-yl)-10,13- } \\
\text { dimethylhexadecahydro-1H- } \\
\text { cyclopenta[a]phenanthren-3-yl acetate } \\
\text { (steroid) }\end{array}$ & \\
\hline
\end{tabular}

solution. However not all of the compounds represented by the peaks may be of relevance in the light of antimicrobial activity. The useful antimicrobial phytochemicals include terpenoids, flavonoids, alkaloids, saponin, and steroids. These categories of phytochemicals have been detected in the extracts and their names are presented in Tables 4-11. The antimicrobial activities of the plant may be attributable to the presence of the identified phytochemicals in the extracts. Terpenes or terpenoids are active against bacteria [17-26]. Flavonoids which are hydroxylated phenolic substances but occur as C6-C3 units linked to an aromatic ring were present in all extracts. Since they are known to be synthesized by plants in response to microbial infection [27], it should not be surprising that they have been found to be effective antimicrobial substances against microorganisms. Their activity is probably due to their ability to complex with extracellular and soluble proteins and to complex with bacterial cell walls similar to quinones. More lipophilic flavonoids may also disrupt microbial membranes [28]. The Euphorbia pulcherrima fractions $\mathrm{A}, \mathrm{B}, \mathrm{C}, \mathrm{D}, \mathrm{E}, \mathrm{F}, \mathrm{G}$, and $\mathrm{H}$ have been found to be largely similar in composition but fraction $\mathrm{H}$ obtained from hexane: ethyl acetate $(7: 3)$ appears to contain more alkaloids and terpenoids than other fractions. Generally the mixtures of hexane and ethyl acetate were more effective than only hexane in the extraction of the phytochemicals from the Euphorbia pulcherrima. 
TABle 10: Phytochemicals in Euphorbia pulcherrima hexane : ethyl acetate (4:1) fraction of ethyl acetate extract (G).

\begin{tabular}{|c|c|c|}
\hline Peak & Name & Structure \\
\hline 1 & $\begin{array}{l}\text { 2,4-Di-tert-butylphenyl 5-hydroxypentanoate } \\
\text { (saponin) }\end{array}$ & \\
\hline 2 & $\begin{array}{c}N^{1} \text {-dodecyl- } N^{2} \text {-(thiazol-2-yl)oxalamide } \\
\text { (alkaloid) }\end{array}$ & \\
\hline 6 & $\begin{array}{l}\text { 7,9-Di-tert-butyl-1-oxaspiro[4.5]deca-6,9-diene-2,8-dione } \\
\text { (flavonoid) }\end{array}$ & \\
\hline 19 & $\begin{array}{c}\text { 4,4,6a,6b,8a,11,12,14b-Octamethyl- } \\
\text { 1,2,3,4,4a,5,6,6a,6b,7,8,8a,9,10,11,12,12a,14,14a,14b- } \\
\text { icosahydropicen-3-ol } \\
\text { (steroid) }\end{array}$ & \\
\hline
\end{tabular}

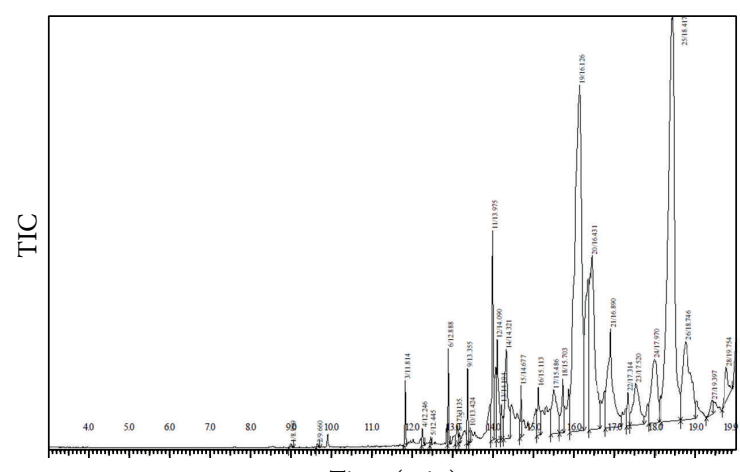

Time (min)

FIGURE 7: GC-MS chromatogram for Euphorbia pulcherrima hexane : ethyl acetate $(4: 1)$ fraction of ethyl acetate extract $(G)$.

All the compounds A, B, C, D, E, F, G, and H showed good activity against the test organisms with zones of inhibitions ranging between 18 and $35 \mathrm{~mm}$ at the highest concentration level $(100 \mathrm{mg} / \mathrm{mL})$.

The bioautography results confirmed the presence of different antimicrobial compounds in the ethyl acetate fraction. All the compounds A, B, C, D, E, F, G, and H showed good activity against the test organisms with zones of inhibitions evident from the clearing of the spots from the TLC plates

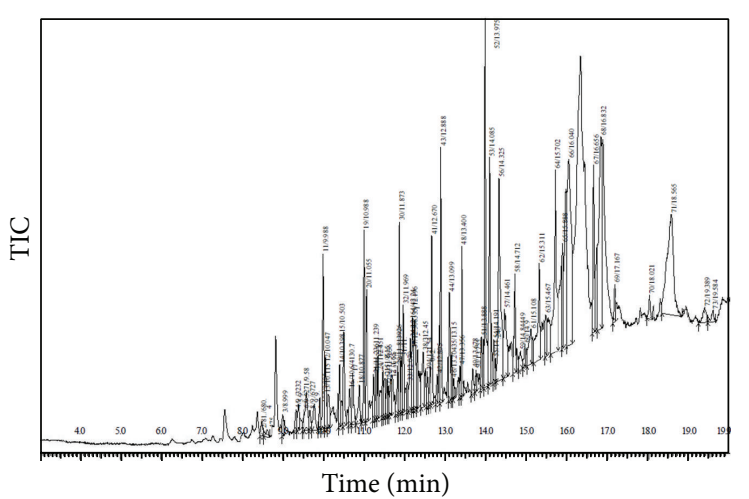

FIGURE 8: GC-MS chromatogram for Euphorbia pulcherrima hexane : ethyl acetate $(7: 3)$ fraction of ethyl acetate extract $(H)$.

(Figure 9). The bioactivity against the test organisms was observed to be attributable to the combined effects of the compounds separated on the TLC plate. This is because all the spots on the TLC plates were cleared consequently upon activity against the test organisms. It is indicative of the synergistic effects of the components of the extract against the test organisms. This finding corroborates the works of Esimone et al. [29]. The identified compounds might have found their way into the cells of the test organisms and 
TABLE 11: Phytochemicals in Euphorbia pulcherrima hexane : ethyl acetate $(7: 3)$ fraction of ethyl acetate extract $(\mathrm{H})$.

\begin{tabular}{|c|c|c|}
\hline Peak & Name & Structure \\
\hline 4 & $\hat{O}_{0}$ & \\
\hline 7 & $\begin{array}{c}\text { 3-(2-Methylprop-1-en-1-yl)-1H-indene } \\
\text { (terpenoid) }\end{array}$ & \\
\hline 9 & 2,3,6-Trimethylnaphthalene & \\
\hline 13 & 2-Phenylbicyclo[3.2.1]octa-2,6-diene & \\
\hline 14 & Undecan-5-ylbenzene & \\
\hline 18 & (4,5,5-Trimethylcyclopenta-1,3-dien-1-yl)benzene & \\
\hline 21 & (2-Methyl-[1,1'-biphenyl]-3-yl)methanol & \\
\hline 31 & Phenanthrene & \\
\hline 39 & 4-Methylnaphtho[1,2-b]thiophene & \\
\hline
\end{tabular}


TABLE 11: Continued.

Peak
43
49
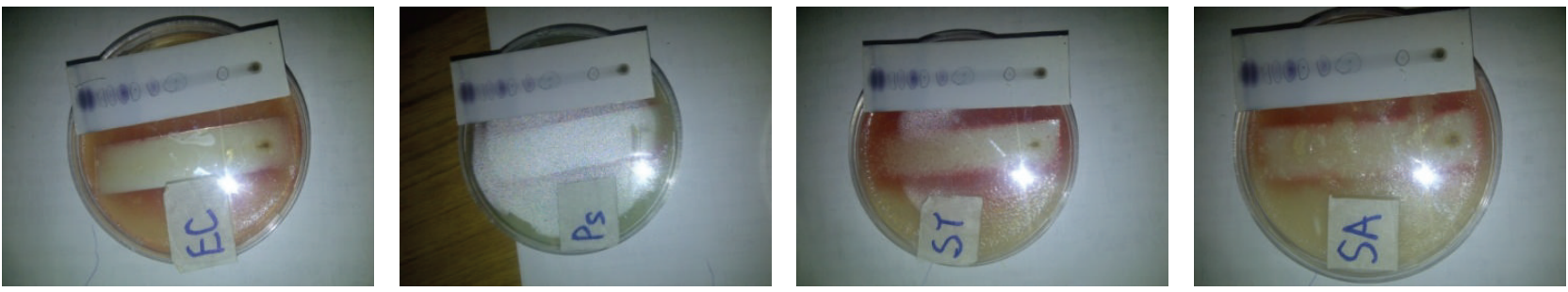

FIGURE 9: Bioautography results of ethyl acetate extract against E. coli (EC), Ps. aeruginosa (Ps), S. typhi (ST), and S. aureus (SA).

ensured the production of efflux pump inhibitors (resistance modifying agents) which may have facilitated the penetration of more phytochemicals into the microbial cells especially of the multidrug resistant organisms. Researches have shown that plant medicinal compounds have resistance modifying activities in vitro [1]. Similarly, Tegos et al. [30] reported that two MDR inhibitors $\left(\mathrm{IN}_{271}\right.$ and $\left.\mathrm{MC}_{207110}\right)$ from Berberine plant were found to have increased the effectiveness of 13 plants antimicrobial compounds against both Grampositive and Gram-negative bacteria including those known to express efflux pumps.

\section{Conclusion}

The ethyl acetate fraction of the methanol extract of the whole plant of Euphorbia pulcherrima contains phytochemicals which have shown remarkable activities against Escherichia coli, Staphylococcus aureus, S. typhi, and Ps. aeruginosa. The bioactivities against the test organisms were due to the combined effects of the compounds separated on the TLC plates. Preparative TLC of the various hexane : ethyl acetate fractions are therefore suggested. This should lead to the isolation of the individual bioactive agent and investigation of their independent bioactivity.

\section{Conflict of Interests}

The authors declare that there is no conflict of interests regarding the publication of this paper.

\section{Acknowledgments}

The authors are grateful to Benedict O. Odjobo, Analytical Unit, Federal Institute of Industrial Research, Oshodi, for the GC-MS analysis and the National Research Institute for Chemical Technology, Zaria, for the FT-IR.

\section{References}

[1] T. Sibanda and A. I. Okoh, “The challenges of overcoming antibiotic resistance: plant extracts as potential sources of antimicrobial and resistance modifying agents," African Journal of Biotechnology, vol. 6, no. 25, pp. 2886-2896, 2007.

[2] A. A. Adedapo, M. O. Abatan, and O. O. Olorunsogo, "Toxic effects of some plants in the genus Euphorbia on haematological and biochemical parameters of rats," Veterinary Archive, vol. 74, no. 1, pp. 33-63, 2004.

[3] E. U. Etuk, B. M. Agaie, P. A. Onyeyili, and C. U. Ottah, "Toxicological studies of aqueous stem bark extract of Boswellia dalzielii in albino rats," Indian Journal of Pharmacology, vol. 38, no. 5, pp. 359-360, 2006.

[4] N. A. Siddique, M. Mujeeb, A. K. Najmi, and M. Akram, "Evaluation of antioxidant activity, quantitative estimation of phenols and flavonoids in different parts of Aegle marmelos," African Journal of Plant Science, vol. 4, no. 1, pp. 1-5, 2010.

[5] K. Kalimuthu, S. Vijayakumar, and R. Senthilkumar, "Antimicrobial activity of the biodiesel plant, Jatropha curcas L," International Journal of Pharma and Bio Sciences, vol. 1, no. 3, article 29, 2010. 
[6] F. O. Ekundayo, C. A. Adeboye, and E. A. Ekundayo, "Antimicrobial activities and phytochemical screening of pignut (Jatrophas curcas Linn.) on some pathogenic bacteria," Journal of Medicinal Plants Research, vol. 5, no. 7, pp. 1261-1264, 2011.

[7] S. Evans and S. Taylor, "Pro-inflamatory, tumor promoting and antitumor diterpene of the plant families Euphorbiaceae and Thymelaeacaeae," in Progress in the Chemistry of Organic Natural Products, W. Herz, H. Griscbach, and G. W. Kirby, Eds., vol. 44, pp. 1-99, 1983.

[8] A. K. Singla and K. Pathak, "Phytoconstituents of Euphorbia species," Fitoterapia, vol. 61, no. 6, pp. 483-516, 1990.

[9] A. Corrêa, R. J. Strasser, and M. A. Martins-Loução, "Response of plants to ectomycorrhizae in N-limited conditions: which factors determine its variation?" Mycorrhiza, vol. 18, no. 8, pp. 413-427, 2008.

[10] A. Kumar, L. K. Sharma, and G. Agarwal, "Medicinal plants for skin and hair care," Indian Journal of Traditional Knowledge, vol. 2, no. 1, pp. 62-68, 2003.

[11] A. Ghani, Introduction to Pharmacognosy, Ahmadu Bello University Press, Zaria, Nigeria, 1990.

[12] I. N. Dobelis, Magic and Medicine of Plants, The Readers Digest Association Inc., 1993.

[13] A. I. Yakubu and M. D. Mukhtar, "In vitro antimicrobial activity of some phytochemical fractions of Euphorbia pulcherima L. (Poinsettia)," Journal of Medicinal Plants Research, vol. 5, no. 12, pp. 2470-2475, 2011.

[14] M. Cheesebrough, Medical Laboratory Manual for Tropical Countries, ELBS, 2002.

[15] S. Murugan, R. Anand, P. Uma Devi, N. Vidhya, and K. A. Rajesh, "Efficacy of Euphorbia milli and Euphorbia pulcherrima on aflatoxin producing fungi (Aspergillus flavus and Aspergillus parasiticus)," African Journal of Biotechnology, vol. 6, no. 6, pp. 718-719, 2007.

[16] National Committee for Clinical Laboratory Standards, "Performance for antimicrobial susceptibility testing," Tech. Rep. Standard M10-S5, NCCLC, Villanova, Pa, USA, 1994.

[17] A. A. Ahmed, A. A. Mahmoud, H. J. Williams, A. Ian Scott, J. H. Reibenspies, and T. J. Mabry, "New sesquiterpene $\alpha$-methylene lactones from the Egyptian plant Jasonia candicans," Journal of Natural Products, vol. 56, no. 8, pp. 1276-1280, 1993.

[18] J. A. Amaral, A. Ekins, S. R. Richards, and R. Knowles, "Effect of selected monoterpenes on methane oxidation, denitrification, and aerobic metabolism by bacteria in pure culture," Applied and Environmental Microbiology, vol. 64, no. 2, pp. 520-525, 1998.

[19] J. T. Barre, B. F. Bowden, J. C. Coll et al., "A bioactive triterpene from Lantana camara," Phytochemistry, vol. 45, no. 2, pp. 321324, 1997.

[20] S. Habtemariam, A. I. Gray, and P. G. Waterman, "A new antibacterial sesquiterpene from Premna oligotricha," Journal of Natural Products, vol. 56, no. 1, pp. 140-143, 1993.

[21] M. Himejima, K. R. Hobson, T. Otsuka, D. L. Wood, and I. Kubo, "Antimicrobial terpenes from oleoresin of ponderosa pine tree Pinus ponderosa: a defense mechanism against microbial invasion," Journal of Chemical Ecology, vol. 18, no. 10, pp. 1809-1818, 1992.

[22] I. Kubo, H. Muroi, and M. Himejima, "Antibacterial activity of totarol and its potentiation," Journal of Natural Products, vol. 55, no. 10, pp. 1436-1440, 1992.

[23] L. Mendoza, M. Wilkens, and A. Urzúa, "Antimicrobial study of the resinous exudates and of diterpenoids and flavonoids isolated from some Chilean Pseudognaphalium (Asteraceae)," Journal of Ethnopharmacology, vol. 58, no. 2, pp. 85-88, 1997.

[24] M. Scortichini and M. P. Rossi, "Preliminary in vitro evaluation of the antimicrobial activity of terpenes and terpenoids towards Erwinia amylovora (Burrill) Winslow et al," Journal of Applied Bacteriology, vol. 71, no. 2, pp. 109-112, 1991.

[25] C. C. Tassou, E. H. Drosinos, and G. J. E. Nychas, "Effects of essential oil from mint (Mentha piperita) on Salmonella enteritidis and Listeria monocytogenes in model food systems at $4^{\circ}$ and $10^{\circ} \mathrm{C}$," Journal of Applied Bacteriology, vol. 78, no. 6, pp. 593-600, 1995.

[26] R. S. L. Taylor, F. Edel, N. P. Manandhar, and G. H. N. Towers, "Antimicrobial activities of southern Nepalese medicinal plants," Journal of Ethnopharmacology, vol. 50, no. 2, pp. 97-102, 1996.

[27] R. A. Dixon, P. M. Dey, and C. J. Lamb, "Phytoalexins: enzymology and molecular biology," Advances in Enzymology and Related Areas of Molecular Biology, vol. 55, pp. 1-69, 1983.

[28] H. Tsuchiya, M. Sato, T. Miyazaki et al., "Comparative study on the antibacterial activity of phytochemical flavanones against methicillin-resistant Staphylococcus aureus," Journal of Ethnopharmacology, vol. 50, no. 1, pp. 27-34, 1996.

[29] C. O. Esimone, M. U. Adikwu, B. Uzuegbu, and A. Udeogaranya, "The effect of ethylenediamine tetraacetic acid on the antimicrobial properties of benzoic acid," Journal Pharmaceutical Research and Development, vol. 4, pp. 1-8, 1999.

[30] G. Tegos, F. R. Stermitz, O. Lomovskaya, and K. Lewis, "Multidrug pump inhibitors uncover remarkable activity of plant antimicrobials," Antimicrobial Agents and Chemotherapy, vol. 46, no. 10, pp. 3133-3141, 2002. 

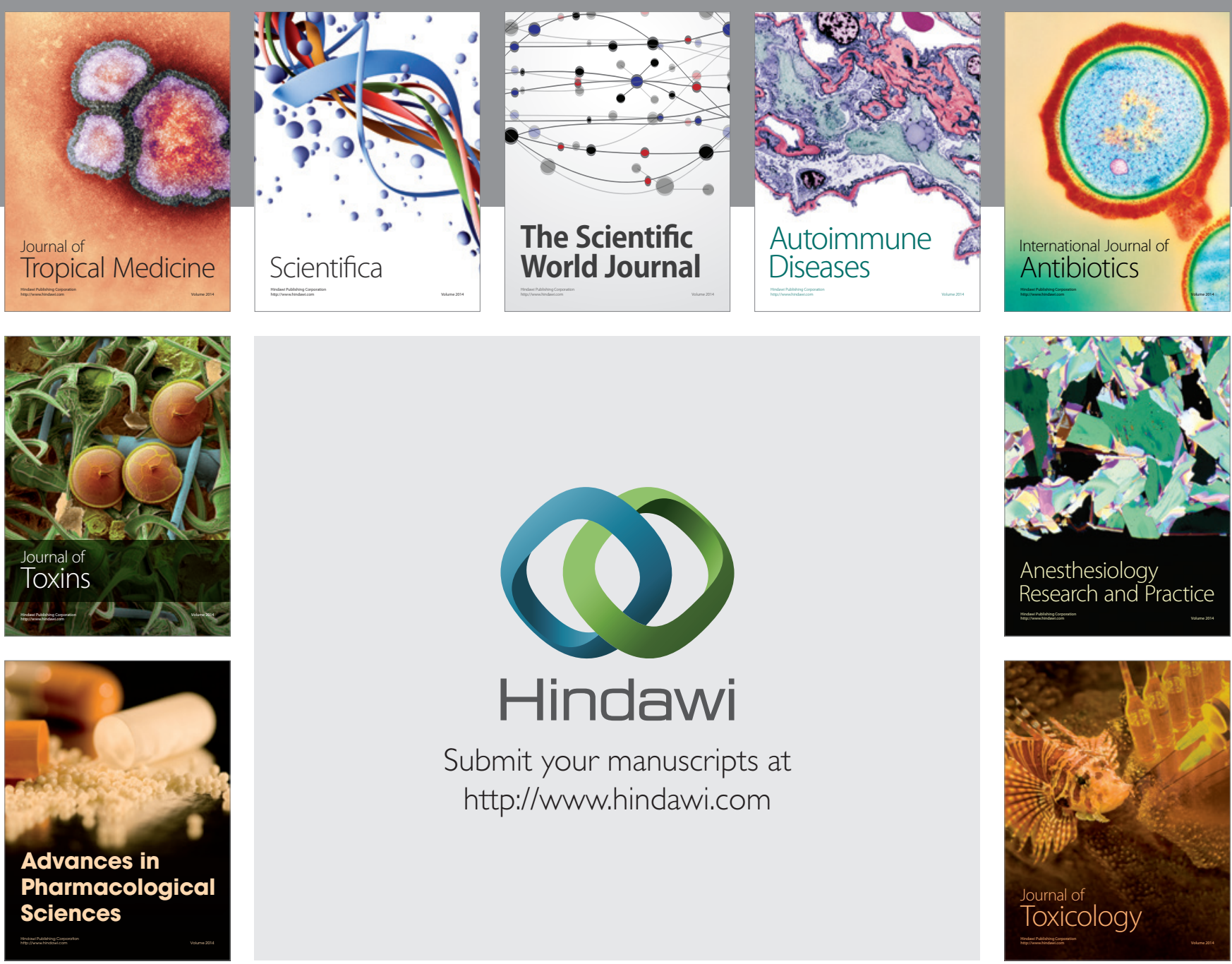

\section{Hindawi}

Submit your manuscripts at

http://www.hindawi.com
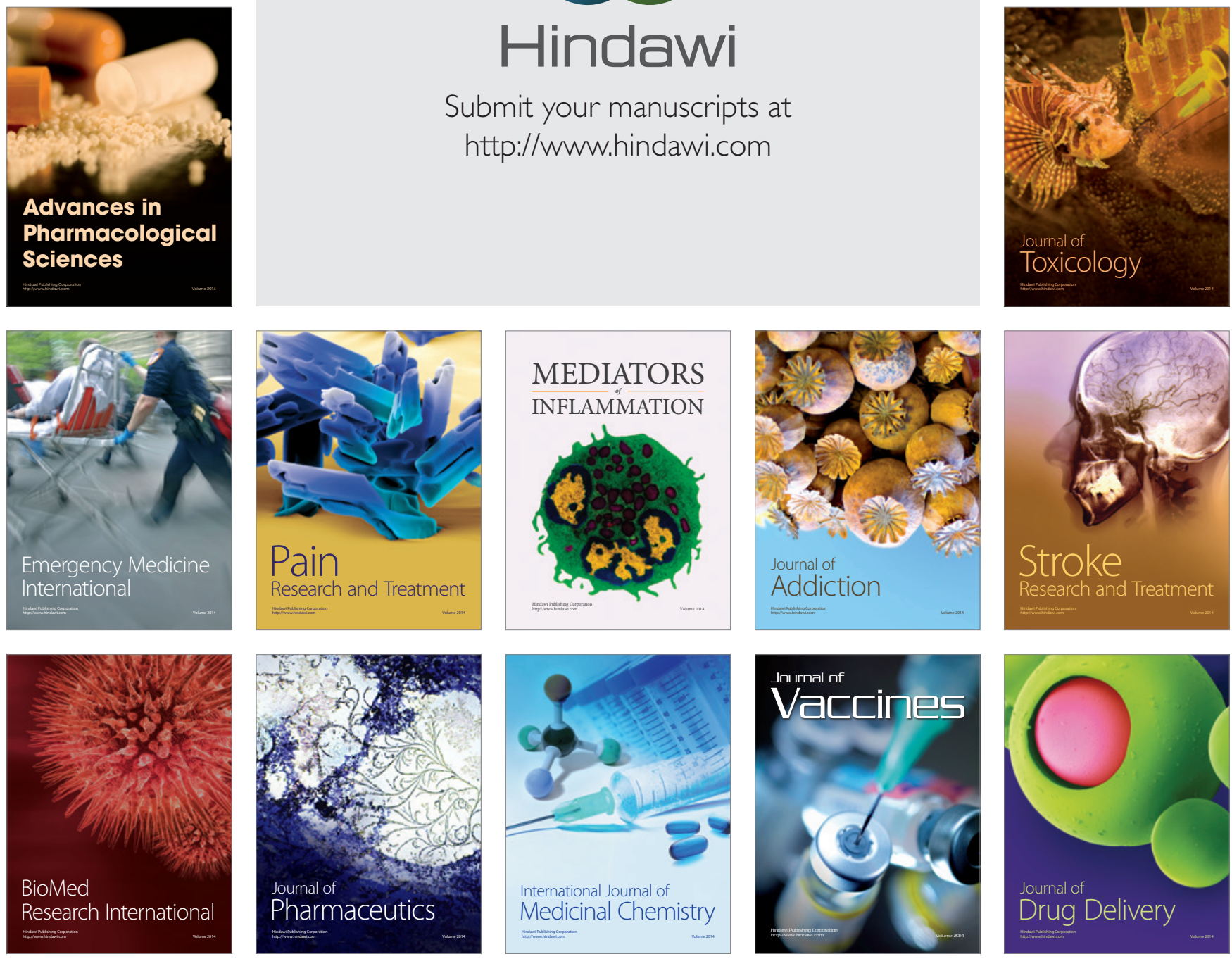